\title{
BETWEEN SCYLLA AND CHARYBDIS: TITLE I'S \\ "COMPARABLE SERVICES" REQUIREMENT AND STATE AND FEDERAL ESTABLISH- MENT CLAUSES
}

\author{
BETSY LEVIN*
}

Title I of the Elementary and Secondary Education Act of $1965^{1}$ provides funds to be used for the benefit of disadvantaged children in need of compensatory educational services, regardless of whether those children attend a public or private school. ${ }^{2}$ In hittle more than ten years of operation, the Title I program has become a vital source of funding for school districts with large concentrations of children from lowincome families. ${ }^{3}$

The 1965 legislation was the first major federal aid-to-education legislation to be adopted since the end of World War $\Pi,{ }^{4}$ ending a twenty-year drought of congressional activity which stemmed in part

* A.B. 1956, Bryn Mawr College; LL.B. 1966, Yale University. Associate Professor of Law, Duke University. Part of this Article is based on a speech delivered by the author at the National School Finance Conference in March, 1975, prior to the Supreme Court's decision in Meek v. Pittenger, 421 U.S. 349 (1975).

1. 20 U.S.C. $\$ \$ 241 \mathrm{a}-\mathrm{in}$ (1970).

2. A "local education agency" may not receive a grant under Title I unless

to the extent consistent with the number of educationally deprived children in the school district of the local educational agency who are enrolled in private elementary and secondary schools, such agency shall make provision for including special educational services and arrangements ... in which such children can participate . . . 20 U.S.C.A. \$ 241e-1(a) (Supp. 1976).

The intent to include nonpublic school children as beneficiaries under Title $I$ is also evidenced by the congressional declaration of policy which pointedly refers to "educationally deprived children" without limiting this class to those educationally deprived children who attend public schools. 20 U.S.C. \$ 241a (1970). The Supreme Court noted in Wheeler v. Barrera, 417 U.S. 402 (1974), that surely "Congress . . . recognized that all children from educationally deprived areas do not necessarily attend the public schools ...." Id. at 405-06.

3. The appropriation for Title I programs has grown from $\$ 1$ billion in fiscal 1966 to $\$ 1.8$ billion in fiscal 1974 . Approximately 6 million children in some 13,900 school districts throughout the country in 1974 were being served by Title I programs. H.R. Rep. No. 805, 93d Cong., 2d Sess. (1974), in 3 U.S. Code Cong. \& Ad. News 4093, 4095 (1974).

4. The only exceptions were the Act of Sept. 30, 1950, ch. 1124, 64 Stat. 1100 and the Act of Sept. 23, 1950, ch. 995, 64 Stat. 967, both federally impacted areas aid. This program provided financial assistance to school districts in areas affected by certain federal activities, such as federal ownership of land or an influx of children whose parents live on or are employed on nontaxable federal property. 
from serious doubts about the extent to which federal aid to parochial schools would impinge upon the prohibitions of the first amendment to the United States Constitution or similar state constitutional bans. ${ }^{5}$ The establishment clause barriers to funding for parochial schools functioned as a political obstacle to federal aid to public schools, since the omission of parochial schools from any substantial aid program would raise strong objections to the consequent discrimination against churchrelated schools. ${ }^{8}$ It was to escape this political-constitutional thicket that Title I expressly earmarks federal funds for disadvantaged children and not as general aid for schools, thus enabling parochial school children to share in the benefits of the Act. ${ }^{7}$

Congress, however, designed the aid program to be administered under the auspices of local (public) school boards, ${ }^{8}$ which in turn are subject to state constitutional limitations on expenditures for nonpublic educational purposes. The result of this congressional arrangement was some confusion over the effect of state law limitations on Title I funds: the inoney comes from the federal treasury, but its use is largely administered by state officials. ${ }^{\ominus}$ Is the spending of Title I funds thus subject to state law prohibitions against appropriations to sectarian educational entities? If so, the impact on the entire Title I program, which must be provided on a comparable basis to both public and private school students, ${ }^{10}$ could be quite substantial, and the program might find itself straitjacketed by the very mechanism which permitted its creation in the first place.

Apart froin these perplexing state law questions, there remains a major question with regard to the first amendment to the Federal Constitution. Title I was indeed drafted as an aid program for all children

5. The principal concerns of Congress were often categorized as the three "R's": Red, Race, and Religion. In addition to the parochial aid issue, other concerns included whether federal aid to education would lead to federal control of education, which traditionally had been a state and local concern and responsibility, and whether federal aid to districts which maintained racially segregated schools could be justified. See J. SuNDQuist, Polttics and Policy: The Eisenhower, Kennedy aNd Johnson Years 15556 (1968).

6. Id. at 188-95.

7. For a general discussion of the enactment of the Elementary and Secondary Education Act, see BaILey \& Mosher, ESEA: THE OfFice of EDucation Administers a Law (1968); Meranto, The Politics of Federal Am to Education in 1965 (1967).

8. 20 U.S.C. \& $241 \mathrm{a}$ (1970); id. \& 244(6)(B).

9. 20 U.S.C.A. $\$ 241 \mathrm{e}$ (a) (Supp. 1976).

10. 45 C.F.R. $\$ 116.19$ (b) (1975). See U.S. DEP'T OF H.E.W., OFFICE OF EDUCAtion, ESEA TTILe I Program GUIDe \# 44, printed in U.S. DEP'T of H.E.W., OfFICE of Education, Trtle I esEa Participation of Private School Children-A HandBOOK FOR STATE AND LOCAL OFFICIALS 39, 41 (1971). 
specifically to avoid the constitutional problems associated with direct aid to parochial schools. Nevertheless, at the time the bill was passed the full ramifications of establishment clause barriers to government assistance to private school students had not been articulated, ${ }^{11}$ and the shape that such aid could take had not been clearly set forth.

Two recent decisions of the Supreme Court, one near the end of the 1974 term, Wheeler v. Barrera ${ }^{12}$ the other in the closing weeks of the 1975 term, Meek v. Pittenger, ${ }^{13}$ have established the broad outlines of the answers to these difficult questions. This Article will examine those decisions, explore their impact on the Title I program, and draw some conclusions about the future directions of federal aid-to-education efforts. ${ }^{14}$

\section{State/Federal Concerns: Wheeler v. Barrera}

The Constitution of the State of Missouri explicitly prohibits the use of any "public funds" to aid sectarian institutions. ${ }^{15}$ In 1966, the

11. As of 1965 , the only decision of the Supreme Court which directly considered the prohibitions of the establishment clause in the context of state aid to private education was Everson v. Board of Education, 330 U.S. 1 (1947). However, after 1965 the Court began to indicate with greater precision what would constitute governinental actions toward private school students. See Meek v. Pittenger, 421 U.S. 349 (1975); Hunt v. McNair, 413 U.S. 734 (1973); Sloan v. Lemon, 413 U.S. 825 (1973); Committee for Pub. Educ. \& Religious Liberty v. Nyquist, 413 U.S. 756 (1973); Tilton v. Richardson, 403 U.S. 672 (1971); Leinon v. Kurtzman, 403 U.S. 602 (1971). See generally Wilson, Lewin, Pfeffer, et al., Commentary: The Sectarian School Aid Decisions, 3 J. LAW \& ED. 101 (1974).

12. 417 U.S. 402 (1974).

13. 421 U.S. 349 (1975).

14. Further clarification can be expected from two suits now pending. The National Coalition for Public Education and Religious Liberty (PEARL), representing numerous education groups nationwide, has brought suit against the Department of Health, Education and Welfare challenging department regulations governing Title I programs which permit publicly paid teachers to teach disadvantaged children in parochial schools. Complaint, National Coalition for Pub. Educ. \& Religious Liberty v. Mathews, Civil No. 76-888 (S.D.N.Y., filed Feb. 25, 1976). See also notes 47-49 infra and accompanying text. PEARL is also considering challenging the by-pass provisions of the Title I regulations. See Educ. Dally, Jan. 30, 1976, at 1. See also notes 54-55 infra and accompanying text.

The American Civil Liberties Union recently filed suits against two Rhode Island school districts and the Rhode Island Department of Education for sending public school teachers, supported by Title I funds, into Catholic schools. Educ. DaILY, Jan. 8, 1976, at 5 .

15. The constitutional provisions are as follows:

[A]ll moneys, bonds, lands, and other property belonging to or donated to any state fund for public school purposes, and the net proceeds ... shall be paid into the state treasury . . . and . . . preserved as a public school fund the annual income of which shall be faithfully appropriated for establishing and maintaining free public schools and for no other uses or purposes whatsoever. Mo. Const. art. 9, $\$ 5$.

Neither the . . . school district or other municipal corporation, shall ever . . . 
Missouri state supreme court prohibited the use of "dual enrollment" as a means of carrying out joint instructional programs for public and nonpublic school children. ${ }^{16}$ Under this system, children who were enrolled fulltime in nonpublic schools were released by their schools several times a week to attend special classes in public schools. ${ }^{17}$ The state court also barred the use of public school teachers on nonpublic school premises to provide speecl therapy programs. ${ }^{18}$ The case, lowever, involved only the use of state funds; thus the opinion did not purport to deal with Title I or any federal education program.

The Missouri State Board of Education nevertheless interpreted the state supreme court opinion as applying to Title I funds, treating federal funds as "public funds" for purposes of the anti-parochial aid provisions in the state constitution. ${ }^{19}$ The State Board attempted to conform its use of Title I funds to the "comparability" requirements of the $\mathrm{Act}^{20}$ and to the restrictions of the state court decision through the following regulations:

(a) [S]hared time or dual enrollment between public and nonpublic schools would not be in conformity with state law. Programs operated in the public school for all clildren after regular school hours, on Saturday, and during the summer after close of the regular school term would be in conformity with state law.

pay from any public fund whatever, anything in aid of any . . . sectarian purpose, or to help to support .... any ... institution of learning controlled by any religious creed . . . I I \& 8 .

[N] o money shall ever be taken from the public treasury . . : in aid of any church, sect or denomination of religion, or in aid of any priest, preacher, minister or teacher thereof, as such; ... no preference shall be given to nor any discrimination made against any church . . . Id. art. 1, \& 7 .

16. Special Dist. v. Wheeler, 408 S.W.2d 60 (Mo. 1966).

17. The Missouri court, interpreting the compulsory school law as requiring students to remain in their own schools for a full six-hour day, found that parochial school children could not, therefore, attend classes in public school buildings during regular school hours, Special Dist. v. Wheeler, 408 S.W.2d 60, 63-64 (Mo. 1966). The United States Supreme Court has not yet been confronted with a first amendment challenge to a dual enrollment plan. Other states, with similarly strict state constitutional provisions, have upheld dual enrollment plans. See, e.g., Morton v. Board of Educ., 69 Ill. App. 2d 38, 216 N.E.2d 305 (1966). The so-called "Blaine Amendment" in New York, N.Y. Const. art. XI, $\S 3$, prohibits any aid to nonpublic schools. This has been interpreted by that state's attorney general as not applying to the use of federal funds in private schools as long as federal funds are kept separate from state and local monies. See Op. N.Y. ATT'y GEN. 36-37 (1975). Thus, in New York, Title I funds could be utilized for dual enrollment programs even if the state prohibited the use of its own funds for such programs. For a discussion of the constitutionality of dual enrollment, see Calhoun, The Elementary and Secondary Education Act and the Establishment Clause, 9 VALPARAISO L. Rev. 487, 504-11 (1975).

18. 408 S.W.2d at 63.

19. See Wheeler v. Barrera, 417 U.S. $402,412-14 \&$ n.9 (1974).

20. See note 10 supra and accompanying text. 
(b) Special educational services and arrangements, including broadened instructional offerings made available to children in private schools, shall be provided at public facilities. Public school personnel shall not be inade available in private facilities. This does not prevent the inclusion in a project of special educational arrangements to provide educational radio and television to students at private schools. ${ }^{21}$

But under any definition, Missouri public school officials were not providing "conparable services" to Title I-eligible students attending nonpublic schools. ${ }^{22}$ These students were provided Title I-funded equipment, materials, and supplies but no personnel services (although in sone Missouri school districts Title I programs held in public school facilities after regular school hours and during the summer were open to all educationally deprived cliildren). By contrast, in the public schools, programs such as remedial reading, remedial arithnietic, and speech therapy were offered during the regular school day. Furthermore, Title I per pupil expenditures between public and private schools were not "comparable." 23 Expenditures ranged from about $\$ 10$ to $\$ 85$ for the disadvantaged nonpublic school student to about $\$ 210$ to $\$ 275$ for the disadvantaged public school student. ${ }^{24}$

One senses that there was a lack of cooperation on both sides. ${ }^{25}$ Public school officials did little to lessen the disparities in the allocation of Title I funds to the parochial schools, while parochial school officials insisted that "coniparable" services, as used in Title I, had to mean both the assignment of public school teachers for reinedial instruction on the premises of the parochial schools and their assignment during the regular school day rather than only during after-scliool hours as was the contention of the public school officials. ${ }^{28}$

The Eighth Circuit Court of Appeals found that the programs provided Missouri's nonpublic school clildren were not comparable, as contemplated by the federal law, and that special services must be provided by the public agency on private as well as public school premises. ${ }^{27}$ Federal law, the court found, determines whether Title

21. See Barrera v. Wheeler, 475 F.2d 1338, 1350 (8th Cir. 1973), aff'd 417 U.S. 402 (1974). Interestingly, the Missouri Attorney General ruled that federal funds are not state public school funds within the meaning of the state constitutional provision. OP. Mo. ATt'y GEN. No. 26 (1970).

22. Wheeler v. Barrera, 417 U.S. 402, 415 (1974).

23. Id.

24. Id. at 410 n.7.

25. Id. at 409.

26. Id.

27. Barrera v. Wheeler, 475 F.2d 1338, 1344 (8th Cir. 1973), aff'd 417 U.S. 402 (1974). 
I funds are to be treated as "state" funds or "federal" funds for purposes of state constitutional and statutory restrictions. ${ }^{28}$ The question was resolved for Missouri by a finding that Title I funds, being federal funds, can be used for personnel services and that expenditures are not subject to state restrictions barring the use of public funds to provide public school teachers to parochial schools. ${ }^{29}$ The court reasoned that Title I appropriations are a federal grant inade "in trust" to local school agencies for the direct benefit of the disadvantaged child, as evidenced by the following:

(1) Title I funds are not to be commingled with other "public funds;"30

(2) Title I funds are not to supplement funds already used for educational purposes in the state; $;$

(3) The state cannot pass a law or interpret its own laws to make a Title I grant "state" or "public funds,"32 and

(4) Title I does not provide school aid to a state or school districtit provides educational services to disadvantaged children. ${ }^{33}$

The Supreme Court, in affirming the circuit court's disposition of the case ${ }^{34}$ took the position that Title I did not require school systems to use publicly employed teachers in parochial schools during school hours if such a practice would violate state law. For the majority, the legislative history of the Act and the language of both the Act and the regulations "reveal[ed] the intent of Congress to place plenary responsibility in local and state agencies for the formulation of suitable programs under the Act."'s5 Thus, the Supreme Court found "specific con-

28. Id. at 1351-52.

29. Id. at 1353.

30. Id. at 1352 .

31. Id.

32. Id.

33. Id.

34. Wheeler v. Barrera, 417 U.S. 402 (1974).

35. Id. at 415-16. The legislative history of the Elementary and Secondary Education Act of 1965 (ESEA) imdicates that Congress was aware of and concerned about possibly conflicting state laws and their effect on the implementation of the Act. See H.R. REP. No. 143, 89th Cong., 1st Sess. 5 (1965), quoted in Wheeler v. Barrera, 417 U.S. 402,416 (1974). The Court also noted that the official handbook prepared by the Office of Education for state and local officials recognizes that "state law is to be accommodated." Id. at 417 n.13. In this publication, the Office of Education explains that there are various state laws which could prohibit the following types of aid to parochial schools (some states have more than one of these provisions):

* Dual enrollment may not be allowed.

* Public school personnel may not perform services on private school premises.

* Equipment may not be loaned for use on private school premises.

* Books may not be loaned for use on private school premises.

* Transportation may not be provided to private school students.

U.S. Dep't of H.E.W., OfFice or Education, Trtue I ESEA Participation 
gressional intent" that "state constitutional spending proscriptions not be pre-empted as a condition of accepting federal funds." ${ }^{36}$

The Court stated in Wheeler that it would expect a state to make the following determinations if Title I funding were sought:

(1) The state must first determine whether Title I funds are "state fund[s] for public scliool purposes" within the proscription of the state constitution.

(2) If the state so construes Title I funds, then federal law inust accommodate itself to the state requirement.

(3) If state law prohibits the use of Title I funds for on-the-premises private sclool instruction, then other services-not proscribed under state law-must be developed.

(4) Since "comparable" services does not mean "identical," the state must design a different program for private schools so as to avoid state restrictions yet still be comparable (and not inferior). ${ }^{37}$

If, in accordance with this scenario, state law is found to prevent on-the-premises instruction in private schools, the Court suggested three remaining options that are still open to the state: ${ }^{38}$

(1) The state can provide "comparable" services, using other than onthe-premises instruction in private schools. ${ }^{39}$ (Justice Blackman provided a laundry list of possible alternatives. ${ }^{40}$ )

(2) If the state is unable to provide "comparable" services, it must develop a plan eliminating the use of on-the-premises instruction in public schools, resorting instead "to other means, such as

of Private School Chimdren-A Handboor for State and Local Offictals 19 (1971).

It has been noted that the constitutions of over thirty states expressiy prohibit the use of any state funds for the support, direct or indirect, of church-related schools. Brademas, The Case for Categorical Aid, in The Polmics of Education at the Local, State and Federal Levels (M. Kirst ed. 1970). Whether federal aid is money "donated to any state fund for public school purposes" within the meaning of the Missouri constitution was, therefore, "purely a question of state and not federal law." Federal law under Title $I$ "is to the effect that state law should not be disturbed." Wheeler v. Barrera, 417 U.S. $402,418-19$ (1974). In addition to the legislative history and reports, Justice Blackmun referred to an express congressional stipulation in the law that

[n]o provision of ... the Elenentary and Secondary Education Act of 1965 ... shall be construed to authorize any department, agency, officer or einployee of the United States to exercise any direction, supervision, or control over the curriculum, program of instruction, adininistration, or personnel of any educational institution, school, or school system . . . . 20 U.S.C. \$1232a (1970), quoted in 417 U.S. at 416.

36. Wheeler v. Barrera, 417 U.S. 402, 416-17 (1974).

37. Id. at 421-23 \& n.17.

38. Id. at 423-26.

39. Id. at 423-25.

40. Id. at 425 n. 20 . 
neutral sites or summer programs that are less likely to give rise to the gross disparity present in [Wheeler]." 11

(3) If that is not acceptable, the state has the option of nonparticipation in the Title I program altogether ${ }^{42}$ - hardly an option likely to appeal to state school officials.

The Supreme Court having held that "comparable" does not mean "identical," ${ }^{43}$ although it must not mean inferior, ${ }^{44}$ Missouri will now have to determine whether a program can be designed which will avoid the state prohibitions yet still be "comparable" within the requirements of Title I. A recent state court decision, Mallory v. Barrera ${ }^{45}$ prohibits the use of Title I funds for on-the-premises private school instruction by public school teachers during regular school hours on the ground that Title I funds are "state funds" within the meaning of the state constitutional proscriptions. The court did not, however, rule out the use of public school teachers on those same premises after regular school hours, or other "acceptable plans" under Title I, ${ }^{4 B}$ although whether such alternative programs are "comparable in quality, scope, and opportunity for participation" remains an as yet unanswered question.

The Department of Health, Education and Welfare is revising its Title I guidelines for the participation of children enrolled in private schools, and the final regulations are expected to be out shortly. ${ }^{47}$ Proposed regulations, released im March, $1975,{ }^{48}$ were drafted to reflect the Supreme Court's decision in Wheeler. The proposed regulations state that

services and activities may be provided to [private school] children which are different froin those provided to public school children. However, ... those services and activities must be comparable in quality, scope, and opportunity for participation to those provided to public school children with needs of equally high priority..$^{49}$

It may well be, then, that Missouri will be able to provide services that are "comparable in quality, scope, and opportunity for participation" through the use of remedial teachers before and after school hours and

41. Id. at 425 .

42. Id. at 425-26.

43. Id. at 420-21.

44. Id. at 422 n.17.

45. Civil No. 782847 (Cir. Ct. Jackson County, Mo., filed Sept. 2, 1975).

46. The court noted that it did not have "either the right or the jurisdiction to fire a judicial blast and sink the Federal gold barge and thus isolate all educationally deprived school children in Missouri from Title I funds." Id. at 9.

47. See Educ. Daily, Feb. 2, 1976, at 5.

48. 40 Fed. Reg. 11,477 (1975).

49. Proposed HEW Reg. \$116a.23(c), 40 Fed. Reg. 11,483 (1975). 
during the summer. Missouri public school officials, prior to the decision in Mallory v. Barrera, had prohibited the assignment of public school personnel to private scliool facilities at any time, thus severely limiting the amount spent per disadvantaged nonpublic school pupil. ${ }^{50}$ One effect of this decision, then, could be to narrow considerably the gap in expenditures between disadvantaged public school and nonpublic school students.

In Wheeler, Justice Blackmun stated at several points that "Title I was not intended to override . . individualized state restrictions." The Act and its legislative history nake clear that Congress intended to impose certain national priorities or interests upon existing state and local structures, without at the sane time disrupting the balance between federal and state powers in a highly sensitive area that, until very recently, had been almost the sole prerogative of state and local officials. ${ }^{52}$ States such as Missouri, by imposing restrictions on the use of Title I funds for disadvantaged children in parochial schools, ${ }^{53}$ are in large part responsible for the enactment in 1974 of the "bypass" amendment to Title $\mathrm{I}^{54}$ only two inonths after the decision in Wheeler v. Barrera. This amendment requires the Umited States Commissioner of Education to "bypass" local educational agencies which, because of state legal restrictions or for any other reason, have failed to provide for the participation of nonpublic school students in Title I programs. Thus the Cominissioner is to arrange for the provision of services to such students directly, using funds from the local education agency's Title I allocation. ${ }^{55}$

50. See notes 23-24 supra and accompanying text.

51. Wheeler v. Barrera, 417 U.S. 402, 421 (1974); see id. at 417, 419.

52. See, e.g., 20 U.S.C. $\$ 1232$ a (1970) (quoted at note 35 supra).

53. A survey undertaken by the U.S. Office of Education at the request of the Eighth Circuit Court of Appeals, Wheeler v. Barrera, 417 U.S. 402, 411 n.8 (1974), indicated that Missouri is the only state in the nation which both prohibits educationally deprived children in nonpublic schools from participating in dual enrollment or "shared time" Title 1 programs (provided in public school facilities or on "neutral territory"), and also prohibits Title $I$ instructional services from being provided to educationally deprived school children on private school premises by public school personnel during regular school hours.

54. 20 U.S.C.A. $\$ 241$ e-1 (Supp. 1976).

55. (b) (1) Waiver of requirement of local educational agency participation

If a local educational agency is prohibited by law from providing for the participation in special programs for educationally deprived children enrolled in private elementary and secondary schools as required by subsection (a) of this section, the Commissioner shall waive such requirement and the provisions of section $241 \mathrm{e}(\mathrm{a})(2)$ of this title, and shall arrange for the provision of services to such children through arrangements which shall be subject to the requirements of subsection (a) of this section.

(2) Arrangements for services where local education agency fails to provide for participation on equitable basis

If the Commissioner determines that a local educational agency has sub- 
The Wheeler opinion will have substantial implications for public and private educators alike. As an initial matter, if the states can determine low federal funds are to be treated, the impact of Title I may be very different among similarly situated states. Illustrative is a decision by Michigan's lighest court, interpreting a strict constitutional prohibition against aid to parochial schools, ${ }^{56}$ one that on its face could be said to be even more restrictive than Missouri's. ${ }^{57}$ The Michigan court reached the following conclusions:

(1) Auxiliary services, interpreted as a benefit to the child, or as aid for "the general health alı welfare" ratler than aid to an institution, are permissible under this constitutional amendment. 58

stantially failed to provide for the participation on an equitable basis of educationally deprived children enrolled in private elementary and secondary schools as required by subsection (a) of this section, he shall arrange for the provision of services to such children through arrangements which shall be subject to the requirements of subsection (a) of this section, upon which determination the provisions of paragraph (a) and section $241 \mathrm{e}(\mathrm{a})(2)$ of this title shall be waived.

(3) Payment of cost of arranged services from appropriate allocations

When the Commissioner arranges for services pursuant to this section, he shall, after consultation with the appropriate public and private school officials, pay the cost of such services from the appropriate allocation or allocations under this subchapter. 20 U.S.C.A. \& $241 \mathrm{e}-1$ (Supp. 1976).

See H.R. Rep. No. 805, 93d Cong., 2d Sess. (1974), in 3 U.S. Code Cong. \& Ad. News 4093, 4109 (1974).

The amendment was adopted because of the difficulty of enforcing the provision that a local education agency was not to receive any Title I funds until it provided for the participation of eligible private school children. Id. The legislative history also notes that this provision was modeled after Title III, which was amended in 1970 to provide such a bypass provision. 20 U.S.C. $\$ 845(f)(1)(1970)$. Title III regulations provide that in the event that "no State agency is authorized to provide, or there is a substantial failure to provide for effective participation on an equitable basis by private school children" the Commissioner is to contract with institutions of higher education or other nonprofit organizations to provide Title III services to such children, the cost to be paid out of the state's allotment. 40 Fed. Reg. 51,016 (1975). The legislative history of the Title III bypass provision makes it clear that the payment of federal funds to private schools or school officials is not permitted. S. REP. No. 634, 91st Cong., 2d Sess. (1970), in 2 U.S. Code CoNG. \& AD. News 2768, 2863 (1970).

The Title I bypass provision may be challenged in a suit filed by The National Coalition for Public Education and Religious Liberty against the Department of Health, Education and Welfare. See note 14 supra.

56. No public monies or property shall be appropriated or paid or any public credit utilized, by the legislature, or any other political subdivision or agency of the state directly or indirectly to aid or mamtain any private, denominational or other nonpublic, pre-elementary, elementary, or secondary school. No payment, credit, tax benefit, exemption or deductions, tuition voucher, subsidy, grant or loan of public monies or property shall be provided directly or indirectly, to support the attendance of any student or the employment of any persons at any such nonpublic school or any location or institution where instruction is offered in whole or in part to such nonpublic school students. The legislature may provide for the transportation of students to and from any school. Mich. CoNST. art. 8, \$2.

57. See note 15 supra and accompanying text.

58. Traverse City School Dist. v. Attomey General, 384 Mich. 390, 417-21, 185 V.W.2d 9, 20-22 (1971). 
These services include the teaching of remedial reading, the counseling of physically handicapped children, speech correction services, and the like. ${ }^{59}$ Even though public school employees provide such services on private school premises, ${ }^{60}$ such services are general health and safety measures "to remedy physical and mental deficiencies of school children and provide for their physical health and safety,"61 and as such, "they have only an mcidental relation to the instruction of private school children." 62

(2) Federal funds, and in particular Title I funds, are not subject to the state constitutional prohibition since

(a) Title I funds are used for auxiliary services (already found to be exempt even when provided solely from state funds ): and

(b) Title I funds are not "public monies", which term refers only to state resources and not federal funds. ${ }^{63}$

Contrast this with the construction of a similar constitutional provision by the Missouri Supreme Court. ${ }^{64}$ That court recently struck down a statute which provided for the lending of books purchased with state funds to students attending both public and nonpublic schools as violative of the state constitutional prohibition on aid to parochial schools. ${ }^{65}$ The Missouri count's view of child benefits or child/parent benefits is thus not nearly as expansive as Michigan's. Indeed, Missouri's constitutional provision is treated by that state as much more restrictive than the first amendment to the Federal Constitution. ${ }^{66}$ One effect of Wheeler, then, may be to move away from a federal policy expressly designed to provide extra resources to meet the educational needs of disadvantaged children, regardless of the nature of the institu-

59. Mich. StAt. ANn. $\$ 15.3622$ (1968).

60. 384 Mich. at 420,185 N.W.2d at 22.

61. Id. at $418-19,185$ N.W.2d at 21.

62. Id. at 419,185 N.W.2d at 22 .

63. Id. at 422-23, 185 N.W.2d at 23-24.

64. See notes 15-16 supra.

65. Paster v. Tussey, 512 S.W.2d 97 (Mo. 1974), cert. denied, 419 U.S. 1111 (1975).

66. See Board of Educ. v. Allen, 392 U.S. 236 (1968). This raises the question of whether at some point a state's decision to go beyond the first amendment's establishment clause in providing for separation of church and state might violate the free exercise clause. "[T]he Court has struggled to find a neutral course between the two Religion Clauses, both of which are cast in absolute terms, and either of which if expanded to a logical extreme, would tend to clash with the other." Walz v. Tax Comm'n, 397 U.S. 664, 668-69 (1970). See also Meek v. Pittenger, 421 U.S. 349, 387 (1975) (Rehnquist, J., dissenting). "Any interpretation of [the Establishment Clause] and the constitutional values it serves must also take account of the free exercise clause and the values it serves." Id. at 395, quoting P. KAUPER, RELIGION AND the Constitution 79 (1964). 
tion which they attend. The majority's opinion in Wheeler has placed Missouri in the position-should the state be unable to devise a plan providing "comparable" services to nonpublic schools-of having to dilute its compensatory programs for all disadvantaged children or having no federal compensatory program at all. ${ }^{87}$

Another question is what Wheeler might mean for other federal aid-to-education programs which provide funds for nonpublic schools, e.g., the National School Luncls Act, ${ }^{88}$ the National Defense Education Act, ${ }^{69}$ and the Bilingual Education Program. ${ }^{70}$ Do state laws similarly restrict the distribution of funds under these programs to nonpublic schools? In holding that federal law under Title I contemplates that state law is not to be preempted but accommodated, the Supreine Court was careful to point out that this result was mandated by the legislative history, the language of the Act, and the regulations pertaining to that Act. Thus, it would seem that where congressional intent is less clear, or where there is a clear congressional purpose to impose national educational priorities regardless of state law, Wheeler should not present an insurmountable obstacle. ${ }^{71}$

\section{The Establishment Clause: Meek v. Pittenger}

After Wheeler v. Barrera, the states still were free to explore several options ${ }^{72}$ in their attempts to reconcile the Title I mandate that federal funds be made available to all eligible children-in public or private schools-with state law prohibitions on the use of public funding for sectarian institutions. The picture was further comphicated, however, when the Supreme Court decided to consider, in Meek $v$. Pittenger, ${ }^{73}$ the first amendment implications of state funding programs which were aimed at achieving some of the same educational goals that were the object of Title I. The precise issue before the Court in Meek was the constitutional validity of state efforts to assist private sectarian

67. 417 U.S. at 425.

68. The National School Lunch Act provides federal funds to defray the costs of school lunches for private school children. 42 U.S.C. $\$ 1759$ (1970).

69. The National Defense Education Act provides loans to nonprofit private schools for the procurement of educational equipment in academic subjects. 20 U.S.C. $\S 445$ (1970).

70. The Bilingual Education Act provides federal funds to private schools using bilingual educational methods in areas where there are children with limited English language skills. 20 U.S.C.A. $\$ 880 b-7$ (b)(2)(c)(ii) (Supp. 1976).

71. See generally Note, The Preemption Doctrine: Shifting Perspectives on Federalism and the Burger Court, 75 CoLum. L. REv. 623 (1975).

72. 417 U.S. at $423-26$. See notes 38-42 supra and accompanying text.

73. 421 U.S. 349 (1975). 
schools through aid limited to the nonsectarian, purely educational functions of such schools. ${ }^{74}$ For those concerned with the vitality of Title I funding, the broader question concerns the scope of the immunity from establishment clause challenge afforded a public aid program by the device of earmarking such funds for children as opposed to the schools themselves. The import for Title I, which largely provides the salaries of remedial inath and reading instructors and which must supply comparable services for both public and nonpublic students, is nuanifest: what kinds of programs can be maintained under Title I without running afoul of first amendinent prohibitions?

Over the course of the last few decades, the Supreme Court lias evolved a three-pronged test for determining whether state or federal action respecting nonpublic school education violates the establishment clause of the first amendment. ${ }^{75}$ The full test was first articulated in Lemon v. Kurtzman ${ }^{76}$ and has been reiterated in more recent Supreme Court cases. ${ }^{77}$ To be upheld, the law being challenged as a violation of the first amendment

(1) must reflect a clearly secular legislative purpose; 78

(2) must have a primary effect that neither advances nor inhibits religion; ${ }^{79}$ and

(3) must avoid excessive government entanglement with religion. ${ }^{80}$

Using this tripartite test, the Court has invalidated a state statute authorizing reimbursement of nonpublic elementary schools for the cost of teachers' salaries, textbooks, and instructional materials in specified secular subjects, and a state statute providing a direct salary supplement

74. For a general discussion of Meek see The Supreme Court, 1974 Term, 89 Harv. L. REV. 47, 104-10 (1975).

75. In Meek the Court said the three-pronged test "constitute[s] a convenient, accurate distillation of this Court's efforts over the past decades to evaluate a wide range of governmental action challenged as violative of the constitutional prohibition against laws 'respecting an establishment of religion,' and thus provide[s] the proper framework of analysis for the issues presented in the case before us." 421 U.S. 349, 358. See cases cited in note 11 supra.

76. 403 U.S. $602,612-13$ (1971).

77. See, e.g., Sloan v. Lemon, 413 U.S. 825, 828-33 (1973); Committee for Pub. Educ. \& Religious Liberty v. Nyquist, 413 U.S. 756, $772-73$ (1973).

78. See, e.g., Epperson v. Arkansas, 393 U.S. 97, 109 (1968). With the growing sophistication of legislative bodies, there seems little likelihood that many legislative enactments would fail this first test.

79. See, e.g., Board of Educ. v. Allen, 392 U.S. 236, 243 (1968); School Dist. v. Sehempp, 374 U.S. 203, 222 (1963).

80. See, e.g., Committee for Pub. Educ. \& Religious Liberty v. Nyquist, 413 U.S. 756, 772-73 (1973). The "entanglement" test was first discussed in Walz v. Tax Comin'n, 397 U.S. 664, 674 (1970), as a component of the "primary effect" test, but it was not used as an imdependent analytical test until Lemon. 403 U.S. at 613. 
to teachers of secular subjects in nonpublic elementary schools. ${ }^{81}$ More recently, the Court has invalidated statutes providing direct grants to nonpublic schools for maintenance and repair of school facilities, tuition reimbursement to parents of children attending nonpublic elementary and secondary schools, and tax "credits" to parents not qualified to receive the tuition reimbursement because of an income cutoff point. ${ }^{82}$

Prior to the Court's decision in Meek v. Pittenger, the only benefits to elementary and secondary sectarian schools which had survived constitutional attack in the Supreme Court were programs under which textbooks were lent to all students in a district, ${ }^{83}$ and those where parents of all school children, including those attending sectarian schools, were reimbursed for bus fares. ${ }^{84}$ The location of the dividing hine between constitutionally valid programs and unconstitutional programs appeared to depend primarily on whether or not the questioned state action became sufficiently enmeshed in the "Catcl-22" situation of trying to satisfy both the "primary effect" and "excessive governmental entanglement" requirements of the three-pronged test. ${ }^{85}$

In Meek v. Pittenger, the Court once again applied the thrcepronged test. ${ }^{88}$ Under one of the challenged statutes in $M e e{ }_{,}{ }^{87}$

81. Lemon v. Kurtzman, 403 U.S. 602 (1971). The statutes involved were those of Pennsylvania and Rhode Island.

82. Committee for Pub. Educ. \& Religious Liberty v. Nyquist, 413 U.S. 756 (1973). The statutes involved were those of the State of New York.

83. Board of Educ. v. Allen, 392 U.S. 236 (1968).

84. Everson v. Board of Educ., 330 U.S. 1 (1947). The Court has also upheld grants of government funds directly or indirectly to sectarian institutions of higher education for the purpose of constructing buildings and facilities to be used exclusively for secular educational purposes. Hunt v. McNair, 413 U.S. 734 (1973); Tilton v. Richardson, 403 U.S. 672 (1971). See generally Note, Private Colleges, State Aid, and the Establishment Clause, 1975 DUKE L.J. 976.

85. Mr. Justice Powell, speaking for the Court in Nyquist, described this phenomenon as an attempt to "sail between the Scylla and Charybdis of 'effect' and 'entanglement.' " 413 U.S. at 788. Lemon v. Kurtzman, 403 U.S. 602 (1971), provides a good illustration of this problem. In that case, the Court implicitly recognized the propriety of a state's furthering its interest in the education of its citizens through support of the secular portion of education in sectarian schools. Id. at 613. The Court also noted that the state properly heeded the constitutional necessity of circumscribing any support of education in nonpublic schools with pervasive regulations designed to assure that such support flowed only to secular educational activities. Id. Because of the dominantly religious character of these sectarian elementary and secondary schools, however, the Court concluded that "the very restrictions and surveillance necessary to ensure that teachers play a strictly nonideological role give rise to the entanglements between church and state." Id. at 620-21.

86. 421 U.S. at 358-59. The Court has, on occasion, mentioned yet another factor -the potential or opportunity for "political fragmentation and division along religious 
Pennsylvania's State Secretary of Education was authorized to provide auxiliary services to all nonpublic school children, such services to include:

guidance, counseling and testing services; psychological services, services for exceptional children; remedial and therapeutic services; speech and hearing services; services for the improvement of the educationally disadvantaged (such as, but not hmited to, teaching English as a second language), and such other secular, neutral, non-ideological services as are of benefit to nonpublic school children and are presently or hereafter provided for public school children for the Commonwealth. ${ }^{88}$

These services were to be provided on the premises of the nonpublic scliools by public school persomiel. ${ }^{89}$

The second act authorized the state educational system to lend textbooks to nonpublic school children ${ }^{90}$ and to lend instructional materials and equipment-imcluding projection, recording and laboratory equipment, maps, cliarts, globes, films, photographs, videotapesdirectly to qualifying nonpublic schools. ${ }^{91}$ The Supreme Court, with Justice Stewart writing for the majority, struck down both acts with the exception of the textbook provision. ${ }^{92}$

lines." Id. at 372. This concern over potential political divisiveness, first expressed in Lemon v. Kurtzman, 403 U.S. 602 (1971), has ususally been treated as an added concern after the first three tests have been applied. "A broader base of entanglement of yet a different character is presented by the divisive pohtical potential of these state programs." Id. at 622. See also Committee for Pub. Educ. \& Religious Liberty v. Nyquist, 413 U.S. 756, 795-97 (1973). Earlier in Walz v. Tax Comm'n, 397 U.S. 664 (1970), Justice Harlan, in a concurring opinion, had stated: "What is at stake as a matter of policy is preventing that kind and degree of government involvement in religious life that, as history teaches us, is apt to lead to strife and frequently strain a political system to the breaking point." Id. at 694. In fact, as far back as Everson v. Board of Educ., 330 U.S. 1 (1947), Justice Black, in reviewing the background against which the first anendment was adopted, noted the "civil strife" caused by sects "determined to maintain their absolute political and religious supremacy." Id. at 8-9.

In Meek, however, Justice Brennan, joined by Justices Douglas and Marshall, attempted to raise this concern to the level of a fourth factor in testing whether a state aid program to sectarian schools violates the establishunent clause, 421 U.S. at 374-79, despite language in Nyquist that this factor "may not alone warrant the invalidation of state laws." 413 U.S. at 797-98. According to Justice Brennan, "the potential for political divisiveness related to religious belief and practice" was "key" to a determination that the statutes in Lemon violated the establishment clause. 421 U.S. at 375.

87. Pa. Stat. ANN. tit. 24, §§ 9-972 et seq. (Supp. 1975).

88. Id. § 9-972(b).

89. Id. § 9-972(c).

90. Id. \& 9-973(c).

91. Id. § 9-973(e).

92. Meek v. Pittenger, 421 U.S. 349 (1975). 


\section{Instructional Materials and Equipment}

While there was no question of whether a valid secular legislative purpose existed, ${ }^{93}$ the Court found that the loan of instructional materials and equipment to nonpublic elementary and secondary schools had the "primary effect" of advancing religion since the beneficiaries were sectarian schools." The Court saw this as a "inassive aid"05 program to church-related nonpublic schools as distinguished from the indirect or incidental aid of, for example, bus transportation or school lunch programs which included church-related schools as part of a program provided for all students. ${ }^{96}$ Even though soine of the materials and equipment to be provided were "self-policing," amount of aid under the statute was such that "it would simply ignore reality to attempt to separate secular educational functions from the predominantly religious role performed" 98 by the church-related schools. Thus, "[e]ven though earmarked for secular purposes, "when it flows to an institution in which religion is so pervasive that a substantial portion of its functions are subsumed in the religious mission,' state aid has the impermissible primary effect of advancing religion."'g9 The Court, therefore, appears to have all but come around to the view that aid of almost any kind to sectarian schools-even if earmarked and precisely tailored for secular purposes- "frees up" other money of the sectarian institution, thereby permitting such "freed-up" money to be spent on the fostering of religion. ${ }^{100}$

\section{Assignment of Public School Employees to Parochial Schools}

The Supreme Court, in Lemon v. Kurtzman, had distinguished statutes which provide textbooks to be lent to all clildren (whether they are attending public or private sectarian schools) ${ }^{101}$ - upheld as

93. Id. at 363 .

94. Id.

95. Id. at 365 .

96. Id. at $364-65$.

97. Id. at 365 .

98. Id.

99. Id. at 365-66, quoting Hunt v. McNair, 413 U.S. 734, 743 (1973).

100. See, for example, Justice Douglas's separate opinions in Wheeler v. Barrera, 417 U.S. 402, 431-32 (1974); Tilton v. Richardson, 403 U.S. 672, 694-95 (1971); and Lemon v. Kurtzman, 403 U.S. 602, 641-42 (1971). See also id. at 660 (Justice Brennan's separate opinion). The majority of the Court, of course, has never accepted this "freeing-up" analysis in higher education cases. See Note, Private Colleges, supra note 84 , at 995 .

101. Board of Educ. v. Allen, 392 U.S. 236 (1968).

102. A Pennsylvania statute, PA. Stat. ANN. tit. 24, $\$ \$ 5601-08$ (Supp. 1974), aided sectarian schools by providing for reimbursement of the cost of lay teachers' salaries in 
constitutional-from statutes which impermissibly provide sectarian schools or teachers with salary payments, ${ }^{102}$ noting that "teachers have a substantially different ideological character from books. ... . [A] textbook's content is ascertainable, but a teacher's handling of a subject is not." ${ }^{103}$ The Court further stated that it could not "ignore the danger that a teacher under religious control and discipline poses to the separation of the rehioious from the purely secular aspects of precollege education." ${ }^{104}$ However, none of the cases to come before the Supreme Court until Meek ${ }^{105}$ had involved the use of public school teachers on private school premises, whether to teach in the core curriculum or to provide auxiliary and remedial services. ${ }^{108}$

specified secular subjects. A Rhode Island statute, R.I. GEN. LAws ANN. §§ 16-15-1 to -9 (Supp. 1973), provided for payments directly to lay teachers of secular subjects in nonpublic schools as a supplement of fifteen percent of their current annual salary.

103. Lemon v. Kurtzman, 403 U.S. 602, 617 (1971).

104. Id. (emphasis added).

105. See Levitt v. Committee for Pub. Educ., 413 U.S. 472 (1973); Committee for Pub. Educ. \& Religious Liberty v. Nyquist, 413 U.S. 756 (1973); Lemon v. Kurtzman, 403 U.S. 602 (1971); Earley v. DiCenso, 403 U.S. 602 (1971).

106. Prior to the Supreme Court decision in $M e e k$, the question of whether the same degree of conflict "inheres in the situation" when public school teachers are sent into private schools had been addressed by a three-judge district court in New Jersey in Public Funds for Pub. Schools v. Marburger, 358 F. Supp. 29 (D.N.J. 1973), aff'd mem., 417 U.S. 961 (1974). The district court responded to the question of whether a public school employee, assigned to a parochial school for certain hours, is a teacher "under religious control" as follows:

The defendants argue that no surveillance would be required to enforce State limitations in the auxiliary program because the processes which would be involved in remedial reading or remedial arithmetic are clearly more peripheral to the possibility of religious indoctrinatiou than the initial teaching of reading and arithmetic. Even though this argument is sound, to a degree, a teacher who teaches reading or remedial reading remains a teacher. A teacher's instruction may vary in content or einphasis and is not entirely predictable. A teacher is not a textbook, the contents of which remain constant, as the Court recognized in Lemon .... . This being so, it would be necessary to continually review the content of a teacher's instruction in order to see that it adheres to the restrictions imposed by the statute, in that it be confined only to secular and non-idcological subject matter.

Moreover, it is clear that the teachers providing such auxiliary services will be functioning within the confines and environment of a given religious institution where a religious atmosphere may be pervasive. Although the teachers of auxiliary services are not einployed by a religious organization and are not directly subject to the direction and discipline of a religious authority, they will, nonetheless, be working in atmospheres dedicated to the rearing of children in a particular religious faith. Again it would seem that a constant review of that instruction would be required in order to determine that the religious atmosphere has not caused religion to be reflected-even unintentionally -in the instruction provided by such teachers. $358 \mathrm{~F}$. Supp. at 40 .

See also Aniericans United for Separation of Church \& State v. Oakey, 339 F. Supp. 545, 553 (D. Vt. 1972); People ex rel. Klinger v. Howlett, 56 Ill. 2d 1, 10-12, 305 N.E.2d 129, 134 (1973).

The three-judge district court which decided Meek v. Pittenger, 374 F. Supp. 639 (E.D. Pa. 1974), aff'd in part, rev'd in part, 421 U.S. 349 (1975), thought differently, 
The auxiliary services provided for in the Pennsylvania statute challenged in Meek were designated for nonpublic school children rather than for the schools. ${ }^{107}$ Nevertheless, the Court invalidated the statute, noting that the "prophylactic contacts" necessary on the part of the state "to ensure that teachers play a strictly nonideological role"108 would trigger the third part of the Lemon test-excessive entanglement between church and state. Despite dicta in Wheeler that auxiliary and conipensatory services, when provided by public school employees a few hours per week on parochial school premises, might survive constitutional scrutiny, ${ }^{109}$ the Meek Court found irrelevant the fact that teachers are utilized "only for remedial and exceptional students, and not for normal students participating in the core curriculum,"110 at least with regard to "the danger that religious doctrine will become intertwined with secular instruction . . . ."111

The Court also found no distinction between the teacliers "under religious control and discipline" present in Lemon v. Kurtzman ${ }^{112}$ and employees of the public school system witl regard to their susceptibility to religious influence:

To be sure, auxiliary services personnel, because not employed by the nonpublic schools, are not directly subject to the discipline of a religious authority . . . . But they are performing important educational services in schools in which education is an integral part of the dominant sectarian mission and in which an atmosphere dedicated to the advancement of religious belief is constantly maintaimed ..... The potential for impermissible fostering of religion under these circum-

however: "The notion that by setting foot inside a sectarian school a professional therapist or counselor will succumb to sectarianization of his or her professional work is not supported by any evidence." $374 \mathrm{~F}$. Supp. at 657.

107. PA. Stat. ANN. tit. 24, § 9-972 (Supp. 1975).

108. 421 U.S. at 370.

109. Justice Blackmun, writing for the majority in Wheeler, was careful to point out that "we intimate no view as to the Establishment Clause effect of any particular program." Wheeler v. Barrera, 417 U.S. 402, 426 (1974). He did note, however, that if state and local agencies decide to comply with Title I requirements by using on-thepremises parochial school instruction

the range of possibilities is a broad one and the First Amendment implications may vary according to the precise contours of the plan that is formulated. For example, a program whereby a former parochial school teacher is paid with Title I funds to teach full time in a parochial school undoubtedly would present quite different problems than if a public school teacher, solely under pub-

lic control, is sent into a parochial school to teach special remedial courses a few hours a week. Id.

Justice Blackmun joined the majority in Meek, however, in its holding unconstitutional the provision of remedial services to parochial school students.

110. 421 U.S. at 370.

111. Id.

112. 403 U.S. 602 (1971). 
stances, although somewhat reduced, is nonetheless present. To be certain that auxiliary teachers remain religiously neutral, as the Constitution demands, the State would liave to impose limitations on the activities of auxiliary personnel and then engage in some form of continuing surveillance to ensure that those restrictions were being followed. ${ }^{113}$

The Court thus found no constitutionally significant distinction between the provisions of auxiliary remedial services and secular subjects which are part of the core curriculum, or between lay teachers hired by the religious institution and state employees.

It was this latter aspect of the Court's opinion to whicl the Chief Justice dissented most vehemently:

[T] here is no basis in "experience and history" to conclude that a State's attempt to provide--through the services of its own state-selected professionals-the remedial assistance necessary for all its children poses the same potential for unnecessary administrative entanglement or divisive political confrontation whicl concerned the Court in Lemon $v$. Kurtzman . . . .114

Similarly, Justice Rehnquist, speaking for himself and Justice White, found that "the opportunities for religious instruction through the auxiliary services program are greatly reduced . . .."115 Justice Rehnquist stated that even if the distinction between such auxiliary services as remedial and guidance services and the core curriculum is only one of degree, the fact that these services are provided by public school eniployees should lead to a "different constitutional result" from the situation where parochial school teachers subject to "religious control and discipline" are involved. ${ }^{116}$

The majority, as at least one commentator has noted, ${ }^{117}$ simply failed to explain why state "surveillance" of the activities of its own employees would involve "excessive governmental entanglement" with religion, even if it were likely that public employees, providing remedial and therapeutic services and subject to the authority of public school officials, would tend to "inculcate religion."

\section{Textbook Loan Programs}

Justice Stewart, writing for himself and Justices Blackmun and Powell, upheld the textbook loan program, finding it indistinguishable

113. 421 U.S. at $371-72$.

114. Id. at 385-86.

115. Id. at 393.

116. Id. at 393-94.

117. See The Supreme Court, 1974 Term, supra note 74, at 108 n.35. 
from that found constitutionally permissible in Board of Education $v$. Allen. ${ }^{118}$ Both Allen and Everson v. Board of Education ${ }^{110}$ suggest that certain benefits which go to all children, whether public or private school students (or their parents), and which benefit sectarian institutions only indirectly, if at all, will withstand attack under the first amendment. "It is . . . well established . . . that not every law that confers an 'indirect,' 'remote,' or 'incidental' benefit upon religious institutions is, for that reason alone, constitutionally invalid."120

Justice Stewart empliasized that like the New York statute upleld in Allen, the Pennsylvania plan provides textbooks to all children free of charge and the books are lent directly to the student and not to the school. ${ }^{121}$ Moreover, the textbooks must be secular textbooks "acceptable for use in any public, elementary or secondary school."122 The Court further narrowed its holding by contrasting the scheme involved in Meek with the New Jersey textbook statute, which was lield unconstitutional by a district court in Public Funds for Public Schools v. Marburger: ${ }^{123}$

[The New Jersey plan was] not designed to extend to all schoolchildren of the State, whether attending public or nonpublic schools, the benefits of State-loaned textbooks. Although New Jersey public school cliildren were lent their textbooks, $\S 5$ of the Nonpublic Elementary and Secondary Education Act, cliallenged in Marburger, provided that the State Commissioner of Education reimburse the parents of nonpublic schoolchildren for money spent to purchase secular, nomideological textbooks. The District Court based its decision that the textbook provisions violated the constitutional prohibition against laws "respecting an establishment of religion" on the fact that the assistance provided-reimbursement for purchased books-was not extended to parents of all students, but rather was directed exclusively to parents whose children were enrolled in nonpublic, primarily religious schools. ${ }^{124}$

Justice Brennan, joined by Justices Douglas and Marshall, dissented from that portion of the Meek opinion which upheld the constitutionality of the textbook loan program on two grounds. The first ground was the existence of "a serious potential for divisive conflict

118. 392 U.S. 236 (1968).

119. 330 U.S. 1 (1947).

120. Committee for Pub. Educ. \& Religious Liberty v. Nyquist, 413 U.S. 756, 771 (1973).

121. Justice Brennan disagreed with this position. See notes 125-30 infra and accompanying text.

122. 421 U.S. at 361.

123. 358 F. Supp. 29 (D.N.J. 1973), aff'd mem., 417 U.S. 961 (1974).

124. 421 U.S. at $362 \mathrm{n} .12$ (emphasis in original). 
over the issue of aid to religion."126 Justice Brennan found that the textbook loan program (to children) would fall just as did the instructional materials and equipment loan program (to schools) simce both depend on continuing annual appropriations and the textbook loan program imvolves "increasingly massive sums."126 To him, this meant that the potential for political divisiveness was great. In addition, Justice Brennan discounted the child benefit theory-that textbooks are lent to students while instructional materials and equipment are lent directly to the schools-since the book program, as actually administered, was handled by the nonpublic school authorities and the state without any involvement of the students or their parents. ${ }^{127}$ Thus the textbook loan was to the schools and not to the students.

Even if the textbooks were lent directly to the students, the size of the aid program and its dependency on continumg annual appropriations, as noted above, would make the factor of political divisiveness the basis on which the program inust founder. ${ }^{128}$ The program, in Justice Brennan's view, was therefore indistinguishable from the programs which provided loans of instructional materials and equipment and auxiliary services to nonpublic schools which the majority had held constitutionally impermissible. ${ }^{129}$

Finally, the Pennsylvania act was distinguishable froin the statute upheld in Allen, according to Justice Brennan, in that the Meek textbook assistance extends only to children who attend nonpublic schools while different legislation provides textbooks to public schools. ${ }^{130}$

\section{Title I ANd The Child Benefit Theory}

In view of the Court's position with regard to the "self-policing" instructional materials and equipinent-that the secular educational functions are so entwined with the predominately rehigious role of these institutions that aid cannot be channeled to the secular function without providing direct aid to the sectarian-the textbook loan program can only be distinguished on the basis of the child benefit theory. ${ }^{131}$ It is

125. Id. at 382. See note 86 supra.

126. Id. at 381-82.

127. Id. at $379-80$.

128. See notes 126-27 supra and accompanying text.

129. Id. at 384 .

130. Id. at 383-84. But see id. at 360 n.8, 390 (Rehnquist, J., dissenting).

131. Id. at 365 . What was in effect a child benefit theory-although it was not so termed-was first used as a basis for upholding a parochial aid program in Everson $v$. Board of Educ., 330 U.S. 1, 17-18 (1947). And it was first rejected in that case as well-in Justice Jackson's dissenting opinion: "It is of no importance in this situation 
not clear, however, how far one can continue to travel constitutionally with this theory. There would seem to be several conditions that still have to be met to withstand a ruling of unconstitutionality.

\section{(1) The program must be designed to benefit all children}

Both Allen and Everson clearly involved benefits for all children, whether public or nonpublic school students (or their parents). Partial tuition reimbursement and tax credit legislation, which has been found by the Court to be unconstitutional, ${ }^{132}$ can be distinguished from Allen and Everson on the ground that in the former plans, economic benefits went only to a special class of parents and their children (those who utilized the parochial schools), while in the latter, the benefits went to all children or their parents, regardless of the school they attended. The busing and book loan programs thus were designed for all children, with those who attend church-related schools being allowed to participate along with all other children. Moreover, since the tuition reimbursement struck down in Nyquist was for secular education only, pohicing of the plan may have involved excessive governmental entangle-

whether the beneficiary of this expenditure of taxed-raised funds is primarily the parochial school and incidentally the pupil, or whether the aid is directly bestowed on the pupil with indirect benefits to the school." Id. at 24 (Jackson, J., dissenting). The child benefit theory was one of the political compromises which permitted the Elementary and Secondary Education Act (ESEA) to be enacted in 1965. See notes 1-7 supra and accompanying text. The ESEA broke the decades-long deadlock over whether federal aid to education constitutionally could be provided to sectarian as well as secular sclools by providing that funds would be used for disadvantaged children, not as general aid for schools, thus enabling parochial school children to share in the benefits of the Act.

Justice Douglas has vigorously dissented from this view of the child benefit theory:

[T] he program here [cannot] be minimized from scrutiny under the Establisl1ment Clause by portraying this aid as going to the children rather than to the sectarian schools. That argument deserves no more weight in the Establisliment Clause context than it received under the Equal Protection Clause of the Fourteenth Amendment. . . .

If the traditional First Amendment barriers are to be maintained, no program serving students in parochial schools could be designed under this Actwhether regular school lours are used, or after-school hours, or weekend hours. The plain truth is that under the First Amendment, as construed to this day, the Act is unconstitutional to the extent it supports sectarian schools whether directly or through its students. Wheeler v. Barrera, 417 U.S. at 432 (Douglas, J., dissenting) (citations omitted).

As noted earlier, see notes 107-08 supra and accompanying text, the auxiliary services in Meek were also designated for nonpublic sclool children rather than the schools. The program failed, however, because it would of necessity lead to "excessive governmental entanglement" with religion.

132. See Franchise Tax Bd. v. United Americans for Pub. Schools, 419 U.S. 890 (1974) (summarily affirming an unreported decision of the District Court for the Northern District of California which had held the California tax credit plan unconstitutional); Committee for Pub. Educ. \& Religious Liberty v. Nyquist, 413 U.S. 756 (1973). 
ment. Alternatively, such a plan would still encounter difficulty with the second aspect of the Lemon test-the primary effect of advancing religion.

(2) The benefit must involve "self-policing" instructional materials" or non-educational benefits ${ }^{134}$

The concept of "self-pohicing instructional materials" is to be construed narrowly. As one court has pointed out, ${ }^{135}$ movie projectors and tape recorders, while seemingly neutral, can also be used for religious purposes. ${ }^{136}$ Continuous review and control would therefore be necessary, and this, in turn, would likely mean excessive governmental "entanglement."137 Teachers, whether subject to "rehigious control and discipline" or public scliool einployees, and whether hired to teach remedial and exceptional students or average students enrolled in the core curriculum, are not self-policing and will require continuing surveillance by the state to ensure that religious instruction is separated froin secular instruction. The only personnel who may still be permitted in private schools are those who, as part of general legislation, are involved in

programs providing bus transportation, school lunches, and public health facilities-secular and nonideological services unrelated to the primary, religious-oriented educational function of the sectarian school. The indirect and incidental benefits to church-related scloools from those programs do not offend the constitutional prohibition against establishment of religion. ${ }^{138}$

(3) The benefit must not be "massive aid" directly to parochial schools but may accrue only incidentally and indirectly to such schools

Even as to self-pohicing items, however, the Court las indicated that a "massive aid" program providing state loans of instructional material and equipment directly to "religion-pervasive institutions"-

133. In Board of Educ. v. Allen, 392 U.S. 236 (1968), the materials involved were secular books on loan to pupils.

134. In Everson v. Board of Educ., 330 U.S. 1 (1947), the payments to parents were reimbursement for bus fare.

135. Public Funds for Pub. Schools v. Marburger, 358 F. Supp. 29 (D.N.J. 1973), aff'd mem., 417 U.S. 961 (1974).

136. $358 \mathrm{~F}$. Supp. at 38-39. Even the lower court in Meek was in agreement as to the potential use of projectors, tape recorders, and cameras for religious purposes. 374 F. Supp. at 661.

137. 358 F. Supp. at 39.

138. Meek v. Pittenger, 421 U.S. 349, 364-65 (1975). 
while possibly avoiding the "excessive governmental entanglement" prong of the test-directly conflicts with the "primary effect of advancing rehigion" aspect. ${ }^{139}$ In Meek (as in Marburger), the support involved a special state legislative appropriation which provided equipment solely for parochial schools (while presumably such equipment in public schools was paid for at the local level). Thus the legislation provided a special benefit for "relatively few religious groups."140

Finally, the fact that the equipment and materials are loaned directly to the parochial school and not to the child or his parents, in contrast to Allen and Everson where the benefit was seen as accruing only indirectly to the school, and the fact that such equipment is to be used in the core curriculum, clearly make the legislation constitutionally impermissible.

To what extent are the three conditions discussed above present in the Title I requirements for the provision of "comparable services" to private school students? To recapitulate: First, Title I requires that federal funds be used to meet the "special educational needs of educationally deprived children in school attendance areas having high concentrations of children from low income families."141 Second, these funds must

be so used (i) as to supplement and, to the extent practical, increase the level of funds that would, in the absence of such Federal funds, be made available from non-Federal sources . . . , and (ii) in no case, as to supplant such funds from non-Federal sources. . . . ${ }^{142}$

Thus, unlike the loan of imstructional materials and equipment involved in Meek, the Title I aid may not be used for the core curriculum but only for the special needs of educationally deprived children above and beyond the regular school program-in the case of public schools, the regular program being funded from state and local funds, and in the case of private schools, from private funds. Therefore Title I programs arguably are not equivalent to a direct grant to the school, inasinuch as Title I's compensatory services add on to what the regular school system would provide, in public schools as well as in private schools, considerably weakening the "freemg up" or "direct aid to the sectarian function" argument. ${ }^{143}$

The supplementing provisions quoted above, however, create an especially difficult problem in the context of nonpublic schools. If

139. Id. at 364-66.

140. See note 152 infra and accompanying text.

141. 20 U.S.C.A. \$ 241e(a)(1) (Supp. 1976).

142. 20 U.S.C. $\$ 241 \mathrm{e}$ (a) (3) (1970).

143. See note 100 supra and accompanying text. 
Title I funds may be used only for supplemental programs, how are "local education agencies" to ensure compliance by parochial school officials without violating the "excessive entanglement" prohibition? The current HEW regulations apparently interpret the statutory supplementing provisions as applying only to public schools:

No project under Title I of the Act will be deemed to meet the special educational needs of educationally deprived children unless the Federal funds made available for that project (1) will be used to supplement, and to the extent practical imcrease, the level of State and local funds that would, in the absence of such Federal funds, be made available for the education of pupils participating in that project; (2) will not be used to supplant State and local funds available for the education of such pupils; and (3) will not be used to provide instructional or auxiliary services in project area schools that are ordinarily provided with State and local funds to children in nonproject area schools. ${ }^{144}$

No reference is inade to alternative private funding sources. The regulatory structure thus rests on what must be termed a very questionable assumption - that no private schools would have budgeted for the provision of Title I-type auxiliary and remedial services in the absence of federal funds. That is, Title I administrators apparently have been content to assume that none of the private schools benefited by the program has been able to take advantage of the fundimg by manipulating its budget. ${ }^{145}$

New regulations proposed in March, 1975, however, can be read as applying the supplementing prohibition to private schools: "Provisions for serving children in private schools shall not include the financing of the existing level of instruction in the private schools." 146 No auditing mechanism is created, and local agencies are simply required to state in project applications how the needs of educationally deprived children were assessed, the number of children who are to participate, and the degree and manner of participation. ${ }^{147}$ Neverthe-

144. 45 C.F.R. $\$ 116.17$ (h) (1975) (emphasis added).

145. For example, it might be imagined that prior to the advent of Title I funding, a private school already provided, or was planning to provide, certain remedial education courses for its disadvantaged students. Upon learning of the availability of Title I funds, the school's administration removed the remedial program from its budget, and shifted the budgeted funds into a capital account for the construction of a new chapel on the school grounds. The current regulations provide no mechanism for assuring that such a "freeing up" would not occur. Although this illustration is an extreme one, it might be argued that changes in educational trends would have led many private schools to utilize tuition and privately contributed funds to supply many of the same services which Title 1 now underwrites.

146. Proposed HEW Reg. $\S 116 a .23(d), 40$ Fed. Reg. 11,483 (1975).

147. Id. 
less, if the prohibition against "financing the existing level of instruction" is to be enforced, it would seen that some type of surveillance by public officials of the programs being provided on parochial school premises must be instituted and must extend to the budgeting process of the benefited private schools. Any sucli surveillance, obviously, would present difficult "entanglement" probleins.

The second point of distinction between the legislation providing for loans of instructional materials and equipinent overturned in Meek and the Title I legislation is that the latter provides funds for disadvantaged children, whether in public or nonpublic schools, making the benefit more analogous to that upheld in Allen; in other words, the purchase of instructional materials is part of a general program of special help to all disadvantaged children. As the majority in Meek einphasizes, "as part of general legislation made available to all students, a State may include churcli-related schools in ... secular and nomideological services unrelated to the primary, religious-oriented educational function of the sectarian scliool."148 This distinction between Title I legislation and that in Meek seems to be the basis for the position of HEW officials that the regulations for implementing the provisions of Title I concerned with the participation of private school children need not be revised with a view to meeting the Meek guidelines. ${ }^{149}$

Finally, one other aspect of the legislation involved in Meek that is arguably different from Title I legislation should be noted, namely the concern for potential political conflict. Justice Stewart, referring to the fact that the appropriations process is such that there will be annual reconsideration of the auxiliary-services statute, ${ }^{150}$ recognized that there could therefore be "successive opportumities for political fragmentation and division along religious lines."151 In Lemon it was noted that "[h]ere we are confronted witl successive and very likely annual appropriations that benefit relatively few religious groups. Political fragmentation and divisiveness on religious lines are thus likely to be intensified."152 Arguably, however, the statutes involved in Lemon and the programs involved in Nyquist ${ }^{153}$-direct money grants

148. 421 U.S. at 364 (emphasis added).

149. Telephone communication with Dr. John Staehle, Chief of Program Services, Office of Education, Department of Health, Education and Welfare, November 20, 1975. See notes 47-49 supra and accompanying text. But see note 14 supra.

150. 421 U.S. at 372.

151. Id.

152. Lemon v. Kurtzman, 403 U.S. 602, 623 (1971) (emphasis added).

153. 413 U.S. 756 (1973). 
for maintenance and repair of nonpublic school facilities, tuition reimbursement for parents of children attending nonpublic schools, and tax rehef for parents not qualifying for tuition reimbursement-are distinguishable from Title I prograins, as well : some of the programs involved in Meek. In Lemon and Nyquist, economic benefits went only to a special class of parents and their children (those who utilized the parochial schools), or to the parochial schools or their teachers directly. In Meek, and even more so with Title I services, the benefits are for all children, whether public or onpublic school students (or their parents). The appropriations may therefore be more readily seen as aiding children; the fact that a child attends a school is relevant only as to the location for distributing such benefits to him. Thus, if the benefits of Title I are seen as being for all children rather than for "relatively few religious groups," perhaps the potential for political divisiveness along religious lines is not as great.

With regard to the use of public school employees on parochial school premises, however, there is nothing in the Meek Court's discussion of auxiliary services which suggests that a valid constitutional distimction can be drawn between such auxiliary services as remedial reading and arithmetic provided for the benefit of all school children in the state, and similar kinds of programs provided under Title I to disadvantaged students from both public and nonpublic schools. Indeed, the Title I guidelines for sucl services do not seem significantly different from the provisions of the Pennsylvania statute. ${ }^{154}$ Consequently, with the seeming exception of programs providing bus transportation, school lunclies, and public health facilities, it appears that Title I-funded public school personnel could not be used even to provide auxiliary, remedial services to educationally deprived children on parochial school premises since teachers are not "self-policing" items. Yet this is the heart of the Title I program. Whether the distinction between those public school employees who teach on parochial school premises during regular school hours and those who teach before or after school hours ${ }^{150}$ is a constitutionally valid one under the first amendment is arguable.

154. Public school personnel may be made available on other than public school facilities only to the extent necessary to provide special services (such as therapeutic, remedial, or welfare services, broadened health services, school breakfasts for poor children, and guidance and counseling services) for those educationally deprived children for whose needs such services were designed and only when such services are not normally provided by the private schools. Proposed Financial Assistance Guidelines for Educationally Deprived Children \$ $116 \mathrm{a} .23$ (f), 40 Fed. Reg. 11483 (1975).

See notes 107-08 supra and accompanying text.

155. This was the distinction relied upon by the Missouri court in Mallory v. Barrera, Civil No. 782847 (Cir. Ct. Jackson County, Mo., filed Sept. 2, 1975). 
It may well be contended that the potential for "impermissible fostering of religion" is considerably reduced when public school persoimel are employed on parochial school premises only after school hours, and thus the need for continuing state surveillance would also be diminished. ${ }^{156}$

Finally, Meek implies some significant limitations on the uses to which federal funds can be put in parochial schools. In addition to the curtailment of Title I discussed earlier-primarily the use of public school employees on private sclool premises during (and perhaps after) regular school hours to conduct auxiliary programs such as remedial reading and arithmetic and to provide counseling-other federal programs may be similarly curtailed. For example, the provision for loans to nonpublic schools in order to obtain educational equipment for academic subjects under the National Defense Education $\mathrm{Act}^{\mathbf{1 6 7}}$ may no longer be constitutionally permissible. Similarly, federal funds to private schools for bilingual teaching may be constitutionally barred. ${ }^{168}$

\section{ConcLusion}

The Supreme Court's decisions in Wheeler v. Barrera and Meek v. Pittenger should have a substantial impact on the future of the Title I program. Utilization of federal funds inay vary substantially from state to state as local public education agencies struggle to comply with the "comparable services" requirements of the program without violating state constitutional prohibitions on aid to nonpublic educational institutions. Whether such restrictions will hamstring Title I efforts in a significant number of states will depend on state court interpretations of state constitutional prohibitions, and on the willingness of states to amend or repeal provisions which stand as barriers to the receipt of federal money.

Apart from the problems stemming from state restrictions on the ability of public school officials to provide "comparable services" to eligible nonpublic school children, the Supreme Court's recent pronouncements on the breadth of the immunity against first amendment attack afforded aid programs by the child benefit theory may jeopardize the heart of the Title I effort-remedial instruction. If the establish-

156. But see Wheeler v. Barrera, 417 U.S. 402, 432 (1974) (Douglas, J., dissenting). 157. See note 69 supra.

158. See note 70 supra. One can simply substitute "bilingual reading" in the Meek Court's statement regarding the use of publicly funded teachers to support this contention: '[W] remains a teacher, and the danger that religious doctrine will becoine intertwined with secular instruction persists." 421 U.S. at 370. 
ment clause stands as a barrier to the use of Title I-funded remedial arithmetic and reading teachers in nonpublic schools, the politicalconstitutional dilemma which dictated the structure of Title I may force a major revamping of federal efforts to provide aid to elementary and secondary education. It will require careful navigation if federal and state administrators are to steer a steady course between the Scylla of "comparable services" and the Charybdis of the first amendment. 
